\title{
First Report of an Ice Cream Cone Bagworm Manatha Conglacia Haettenschwiler (Lepidoptera: Psychidae) in Oil Palm Plantations of Central Kalimantan, Indonesia
}

\author{
Fitrah Murgianto ${ }^{1, *}, E_{\text {Edyson Edyson }}^{1}$, Yendra P Setyawan ${ }^{2}$, Lukas M Tamba $^{1}$, Adhy
}

\author{
Ardiyanto $^{1}$, and Abdurrahman $\mathrm{H}_{\text {Siregar }}{ }^{3}$
}

\author{
${ }^{1}$ Bumitama Gunajaya Agro Research Center, Palangkaraya, Indonesia, 74354 \\ ${ }^{2}$ Pest \& Entomology Section, Crop Protection Department, SMART Research Institute, Riau, Indonesia, 28112 \\ ${ }^{3}$ Estate Operational, PT Bumitama Gunajaya Abadi subsidiary PT. Bumitama Gunajaya Agro \\ *Corresponding author. Email: fitrah.murgianto@bumitama.com
}

\begin{abstract}
Bagworm is a defoliating insect in oil palm plantations that recently became the main problem since reported can decrease the production significantly. Metisa plana, Mahasena corbetti, Pteroma pendula are types of bagworms can be found in several areas in Indonesia. The objective of this study was to identify bagworm species (Lepidoptera: Psychidae) on oil palm plantation in PT Bumitama Gunajaya Abadi in Pangkalan Bun, Central Kalimantan, Indonesia. A total of 75 bagworms based on survey results from 12 oil palm plant blocks ( \pm 360 hectares) were collected and brought to the Pundu Entomology Laboratory for identification. The bagworm was identified as Manatha conglacia known as an ice cream cone bagworm based on morphological characteristics of the bag. The results of the census revealed that the highest population was found in block W60 with a total population rate of 5.62 larvae of bagworms per frond. This new bagworm report has now become guidance for identification for type of bagworm attack in PT Bumitama Gunajaya Agro, since this bagworm can cause serious damage with defoliating as other types of bagworms.
\end{abstract}

Keywords: Defoliating insect, Emerging bagworm, Leaf-eating caterpillar, Psychidae.

\section{INTRODUCTION}

The increasing expansion of oil palm plantation in Indonesia has resulted in a large monoculture. The extension of monoculture is strongly associated with the appearance of pests. Epidemiologically, the outbreak of several types of pests reported attacking and infecting the oil palm plantation. The bagworm becomes one of the main pests in plantations. Some of the bagworm species such as Metisa plana, Mahasena corbetti, and Pteroma pendula were reported to be the main pests could be found in oil palm hugely [1]. Besides that, the various bagworms were also reported including Clania tertia, Amatissa cuprea, Brachcyttarus griseus, Oiketicoides sp., Cryptothelia cardiophaga, Manatha albipes and other species of these genera $[2,3]$.
The control methods using insecticides have been employed to control the bagworm outbreak. However, continued outbreaks occurred for the past 20 years and impacted seriously on losses of production [4-6]. The severity of attacks in those complexes had given considerable cause for concern. The existence of incomplete control then results in significant losses [7].

Bagworm outbreaks on oil palm plantations can cause significant economic losses [5, 7]. The damage from moderate to heavy defoliation of the oil palm fronds resulting in a significant loss of productivity to $44 \%[7$, 8]. During the period from 1981 to 1985 , more than 10,000 ha of oil palm were seriously attacked by bagworms [9]. MPOB recorded that bagworm were quite a serious problem in the oil palm industry as 35,657 ha was attacked by these pests in 2005 [10]. A surveyed in the middle 60 s to 1990 which had shown little incidence 
before 1990, indicated that from then on, there was an increasing appearance of bagworms, reaching over $12 \%$ of the estate area [6]. Apart from these cases, various species and environmental factors have a major affected on insect population dynamics $[11,12]$. It is suspected that other bagworm species have the potential to become the main pest on oil palm plantations in the future.

Bagworm Manatha conglacia is known as a minor pest in Papua New Guinea oil palm plantations [13]. Nevertheless, hitherto the existence of $M$. conglacia in oil palm plantations in Indonesia never been reported and observed elaborately. Therefore, this study aims to identify the presence of this pest in oil palm plantations in Indonesia especially in the province of Central Kalimantan. Furthermore, it is also can define or give an important information due to the way how to eradicate and control the pests in practical scenario through development of bioecological system in the future.

\section{METHODS}

\subsection{Location and time of study}

Oil palm leaves heavily colonized by bagworms were collected from oil palm plantations (Bumitama Gunajaya Abadi) in Pangkalan Bun, District of West Kotawaringin, Central Kalimantan Province, Indonesia. Bagworms were collected on February 11th, 2021.

\subsection{Bagworm identification}

A total of 75 bagworms based on census results from 12 oil palm plant blocks ( \pm 360 hectares) were collected and put into a labelled plastic container containing oil palm leaves, then brought to the Pundu Entomology Laboratory for identification. The identification was carried out based on the character of the bag according to the instructions in the publication "New bagworms (Lepidoptera, Psychidae) from oil palm plantations in Papua New Guinea" [13]. Recognition is made by measuring bag length and bag morphology $[6,9]$.

\subsection{Bagworm population census}

Manatha conglacia population census starts from the east to west, starting from the 3rd row, then 13th, 23rd, $33 \mathrm{rd}$ and so on every 10 rows of plants in each census block. In the first census line (row 3 ), 3 census points are determined, namely trees 5 th, 15 th, and 25 th or every 10 trees from 32 oil palm trees in one planting row. Furthermore, in the second census line (row 13) 3 census points are further determined with the same pattern for every 10 trees. And so on is determined systematically. Determination of frond samples at the census point can be seen from the fronds showing the heaviest symptoms of damage due to bagworm attacks. All bagworms found were then counted and recorded in a census format.

\section{RESULT AND DISCUSSION}

\subsection{Morphological character of bagworm}

The bagworm species attacking oil palm plantation in Pangkalan Bun was identified as an ice cream cone bagworm, M. conglacia hattenschwiler (Lepidoptera: Psychidae). It is revealed that, based on the morphological characteristic of the bag it was confirmed as $M$. conglacia. Bag shorter than $22 \mathrm{~mm}$ (Figure 1.A), bag without any obvious plant material, deeply ribbed (conspicuously cone-shaped and living on leaflet undersides (Figure 1.B). The bag of the adult instar is different from the bag of the young instar. The bag on the young larva is fully ribbed, while in the adult instar the ribbed is only half of the bag (Figure 1.C).

Generally, bagworms are pests in the immature stages. The larva type is eruciform with a welldeveloped and scleritonized head and thoracic legs [8, 14]. They are characterized by the possession of cases, which they inhabit throughout their development. It begins to build the early case as soon as it hatches. The case was constructed from the part of the leaflet. Bagworms add material to the front of the case as they grow, excreting waste materials through the opening in the back of the case [14]. When it becomes an adult, only adult males ever leave the case to flight to find a mate. The adult males are small, dull-coloured and possess wings. Most species are strong fliers with well-developed wings and feathery antennae [15].

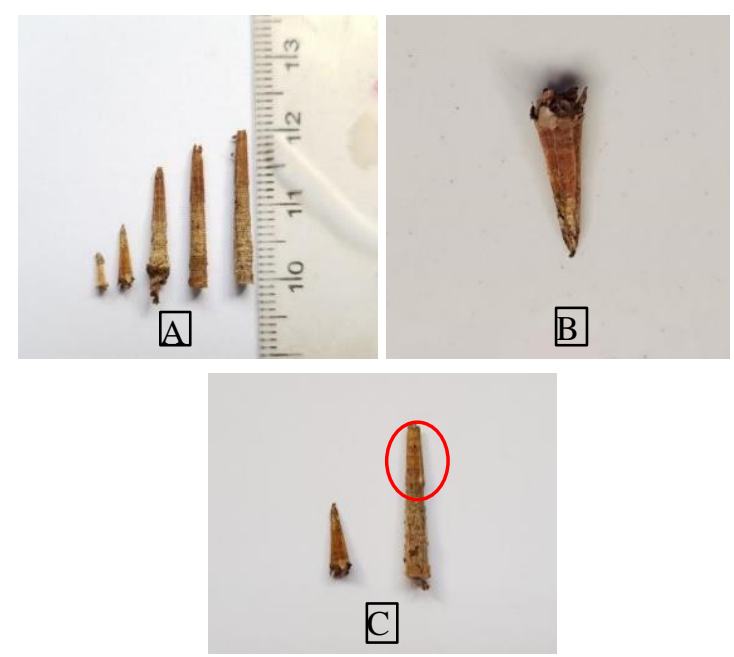

Figure 1. Morphological character of $M$. conglacia. (A) size different from the young to adult instar, (B) deeply ribbed and cone-shaped (C) comparison of the young and old bag.

The case or bag of this species is unique and different from the other species. One of the main characters to identify the bagworm is from the case. The materials used for constructing bags differ among bagworm species; e.g., tree/herb/grass leaves, lichens, twigs, petioles, bark fragments, wood debris, and sand particles. And also 
Table 1 The population of $M$. conglacia based on commercial census in the observed block

\begin{tabular}{|c|c|c|c|c|}
\hline Estate & Block & Date of census & Bagworm / frond a & Position \\
\hline \multirow{12}{*}{ SLNE } & A 56 & \multirow{12}{*}{ February 11th 2021} & $3.28 \pm 4.07$ & \multirow{12}{*}{ The underside of old fronds } \\
\hline & A 57 & & $3.60 \pm 4.46$ & \\
\hline & A 58 & & $4.25 \pm 3.10$ & \\
\hline & A 59 & & $2.67 \pm 2.67$ & \\
\hline & A 60 & & $0.02 \pm 0.16$ & \\
\hline & A 61 & & $0.48 \pm 0.81$ & \\
\hline & W 56 & & $0.60 \pm 1.05$ & \\
\hline & W 57 & & $2.78 \pm 5.49$ & \\
\hline & W 58 & & $2.91 \pm 3.94$ & \\
\hline & W 59 & & $2.10 \pm 2.78$ & \\
\hline & W 60 & & $5.62 \pm 17.44$ & \\
\hline & W 61 & & $0.28 \pm 0.56$ & \\
\hline
\end{tabular}

surface structure becomes a distinguishing character to identify among others [16]. The portable bags are generally believed to play an important role as portable armor against natural enemies [5, 14].

\subsection{Damage and bagworm population}

Young larvae of $M$. conglacia scrape the epidermis of the leaflet (Figure 2.A) while older larvae chew through the leaves making holes at the leaves (Figure 2.B). However, the damage to leaflets caused by M. conglacia looks like gunshot pellet holes where the larvae have chewed through the leaf tissue, or where the leaf layers have been eaten away and the dry (pale-colored) center falls out [17]. On the flip side, For Metisa plana to change from scrapping to cutting the leaflet after the 5th larval instar with instar 7 removing the greatest amount of tissue [9]. In a severe an outbreak the larvae tend to concentrate on the upper fronds but, since necrosis and damages occur gradually as new fronds are emerging in the top of the crown [6], the lower fronds may seem to be more



severely damaged.

Figure 2. (A) Leave damage by a young bagworm and (B) the oldest bagworm of M. conglacia.

Based on the results of the census that has been carried out, the highest population was found in block W60 with a population rate of 5.62 larvae of bagworms per frond (Table 1). While in other blocks the population was still below the pest critical level. The pest critical level of $M$. conglacia was 10 larvae/frond. Chemical control might be immediately implemented when the pest has reached its critical level. However, due to increasing awareness of environmental safety, the biological control uses pests' natural enemies has become the main focus by many estates. The biological control using pest's natural enemies in maintaining the pest population density at a lower average than it would occur in their absence [18, 19].

\section{CONCLUSION}

The species of bagworm which attacked oil palm plantations in Pangkalan Bun, Central Kalimantan is an ice cream cone bagworm $M$. conglacia. However, the pest attack is still below the pest critical level. Implementation of proper monitoring is an important component for efficient monitoring before an outbreak of this pest. The knowledge of the biology of these pests, recognition of behaviours and their damage symptoms are important for early detection.

\section{ACKNOWLEDGMENTS}

We would thank to the Management of Bumitama Agri Ltd for their support in carrying out this research

\section{REFERENCES}

[1] R.H.V. Corley and P.B. Tinker. 2015. The Oil Palm: Fifth Edition., USA: Wiley-Blackwell.

[2] R. Syed and H. Speldewinde. 1974. Pest detection and census on oil palms. The Planter, 50: p. 230233.

[3] C. Teh 1996. Integrated pest management of leafeating caterpillars of oil palms in Sabah. The Planter, 72: p. 395-405.

[4] W.N.M.Wan Abd Halim., et al. 2018. Evaluation of infestation in parasitoids on Metisa plana Walker (lepidoptera: Psychidae) in three oil palm plantations in peninsular Malaysia. Serangga, 22: p. 243 
[5] M.W. Basri, N. Kamarudin, and A.B. Hamdan. 1995. Natural enemies of the bagworm, Metisa plana Walker (Lepidoptera: Psychidae) and their impact on host population regulation. Crop Prot, 14: p. 637-645.

[6] Ho, C., I. Yusof, and K. Khoo. 2011. Infestations by the bagworms Metisa plana and Pteroma pendula for the period 1986-2000 in major oil palm estates managed by Golden Hope Plantation Berhad in Peninsular Malaysia. J. Oil Palm Res. 23: p. 1040-1050.

[7] H. Priwiratama., et al. 2019. Effect of bagworm Pteroma pendula Joannis attack on the decrease in oil palm productivity. JHPT Tropika, 19: p. 101.

[8] N. Kamarudin and M.B. Wahid. 2010. Interactions of the bagworm, Pteroma pendula (Lepidoptera: Psychidae), and its natural enemies in an oil palm plantation in Perak. J. Oil Palm Res, 22: p. $758-764$.

[9] Basri, M., H. Abdul, and M. Zulkifri. 2010. Bagworm (Lepidoptera: Psychidae) of oil palms in Malaysia. J. Oil Palm Res, 23: p. 1-23.

[10] H. Norman and M. Basri. 2007. Status of common oil palm insect pests in relation to technology adoption. Planter,.83: p. 371-385.

[11] J.M. Knops, et al. 1999 Effects of plant species richness on invasion dynamics, disease outbreaks, insect abundances and diversity. Ecology Letters, 2(5): p. 286-293.
[12] A. Khaliq., et al. 2014. Environmental effects on insects and their population dynamics. Journal of Entomology and Zoology Studies 2014. 2(2): p. 17.

[13] P. Hattenschwiler., et al. 2013 New bagworms (Lepidoptera, Psychidae) from oil palm plantations in Papua New Guinea. Mitteilungen der Schweizerischen Entomologischen Gesellschaft, 86: p. 43-260.

[14] M. Rhainds, D.R. Davis, and P.W. Price. 2009. Bionomics of bagworms (Lepidoptera: Psychidae). Annual review of entomology, 54: $\mathrm{p}$. 209-226.

[15] CSIRO, The Insects of Australia. 1970, Commonwealth Scientific and Industrial Research Organisation: Melbourne.

[16] M. Sugimoto. 2009. A comparative study of larval cases of Japanese Psychidae (Lepi- doptera). Japanese Journal of Entomology, 12: p. 1-15.

[17] M. Ero. 2015. Bagworms (Lepidoptera: Psychidae) as Pest of Oil Palm in Papua New Guinea. PNG: Oil Palm Research Association Inc.

[18] N. Sapian, T. Lay, and C.C. Tey. 2011. Evaluation of Beneficial Plants as Hosts for Natural Enemies of Oil Palm Bagworms.

[19] A.D. Advento., et al. 2012. Bagworm Clania tertia Templ. (Lepidoptera: Psychidae): A new emerging pest in oil palm plantation in Indonesia, in MPOB. p. 14-19. 